\title{
Sobel Statistical Test on the Mediation Effect of Halal Image toward Intention to Patronage Retail Stores
}

\author{
Abang Sulaiman Abang Salleh, Norazah Mohd Suki, Norzaihan Hashim, Abang Sulaiman Abang \\ Naim, and Norlelawati Ismawi
}

\begin{abstract}
The term "halal image" may often be referred to any images which are perfectly fit to describe Islamic decency and wholesomeness. As Islam teaches its followers on what foods are good (halal) and bad (haram) for consumption the attachment of Islamic decency and wholesomeness onto retail services is expected to spur store patronage. This research study tries to investigate the power of halal image in maneuvering Muslim consumers toward patronizing retail stores that are guided by the law of syari'ah. In this study, three independent variables (attitude, subjective norm, and perceived behavioral control) have been examined against the intention to patronage retail stores while letting the halal image to intervene. Results of the research study found that the mediating effect of halal image do exist in the relationship between consumers' attitude, subjective norm, perceived behavioral control and behavioral intention to patronage retail stores. This suggests that consumers may perceive halal image as an important part in an indirect positive relationship between independent variables (e.g. attitude, subjective norm, and perceived behavioral intention) and behavioral intention, thus giving support to the mediating effect of halal image. A possible explanation for this mediating effect is probably due to the high degree of dependency on halal image among Muslim consumers.
\end{abstract}

Index Terms - Halal dietary law, behavioral intention, halal retail stores, halal image.

\section{INTRODUCTION}

Muslim consumers' projection toward becoming a major driving force to the world economic growth seems to be promising in the near future. Identified as the fourth-billion market segment [1], Muslim consumers whose population stand at $1.5-1.8$ billion could give much greater impact in comparison to other billions (India - 1.195 billion, China 1.342 billion and Women - consists about half of the world's adult population). According to [1], such a contribution is planned due to certain exceptional qualities which subsist in the segment. First, Muslim consumers are found to exist in economically feasible numbers in many countries worldwide. Second, Muslim populations are the youngest along with all other populations. Finally, a stern support can be clearly seen from quite a number of multinational companies such as McDonald, KFC, Unilever, Nestlé, L'Oreal, Baskin Robbins, Campbell and numerous

Manuscript received March 23, 2020; revised June 11, 2020.

Abang Sulaiman Abang Sallehr, Norzaihan Hashim, Abang Sulaiman Abang Naim, and Norlelawati Ismawi are with Universiti Teknologi Mara Cawangan Sarawak, Thailand (e-mail: abgsulaiman@gmail.com, norahashim10@gmail.com, eman@uitm.edu.my,nismawie@gmail.com).

Norazah Mohd Suki is with Universiti Utara Malaysia, Thailand (e-mail azahsuki@yahoo.com). others who put in great effort in the halal market.

The significant of halal images to marketers should not be taken for granted. High call for halal foods and other halal products is acknowledged not only in Islamic countries but also in the non-Muslim nations where Muslim communities become more apparent. Most Muslim countries are quite well advanced in ensuring more halal foods and products are circulating in their markets. Halal certification seems to be the most demanding instrument being applied to guarantee that food and non-food products are prepared according to the law of syariah [2]. For instance, halal logo will be produced to the manufacturer, food operators, and many others who seek the halal certification. The logo signifies that the foods or products available are halal compliant and sacredly good for Muslim consumption [3] and absolutely, this will grant superb halal confidence to consumers.

Halal images are not only restricted to the conformed halal certified products lay in the retail shelves but more than that the images are seen to take in the stores' internal as well as external looks. Apart from halal logo and halal certification, halal images may also pop up from various identifications such as Muslim store owners, Muslim staffs, composition of Muslim consumers patronizing the stores, hygienic handling, and management of non-halal items, to name a few.

This research study is carried out to examine the relationship between attitude, subjective norm, perceived behavioral control, and consumers' behavioral intention. In addition, halal image is attached in the study's theoretical framework to function as a mediator. Both internal and external looks of the stores contribute to the formation of retail stores' halal image while halal knowledge is to largely contribute to the development of consumer's ideal halal perception. A well balance matching between consumers' ideal halal perception and retail stores' halal images is projected to yield a strong feeling toward intention to patronage the retail stores in the future.

\section{OBJeCtIVE OF THE STUDY}

This research study seeks to investigate the potency of halal image affecting consumers' behavioral intention. Hence, two research objectives are proposed:

a. To investigate the relationship between attitudes, subjective norm, and perceived behavioral control toward behavioral intention to patronage retail stores.

b. To examine the mediating effect of halal image toward the relationship between attitudes, subjective norm, and perceived behavioral control on 
consumers' behavioral intention to patronage retail stores.

\section{HALAL IMAGE AND THE CONCERN FOR HALAL PURCHASING}

Anxiety of Muslim consumers with regard to halal status declared by many food producers were seen as an important driver to avoid the non-halal and at the same time to strictly get complied with halal dietary laws. A study by [4] was such a good example of work research in endorsing the effects of halal principle over consumers' behavior. His research finding revealed that Muslim consumers tend to go for the halal and stay away from the haram. The same research finding was found in a study conducted by [5] who disclosed that Muslim consumers are highly supportive about consumption of halal foods. Such tendency was also recorded in [6].

A similar concern was explained by [7] who found out that Muslim consumers in actual fact care about the halal status of their purchases. This was further supported by [6] who noted that Muslim consumers, as compared to their non-Muslim counterparts, tend to purchase products labeled with halal logo. A study done by [8] also emphasized halal logo as one of the factors to influence customer preference. The important of halal logo was further demonstrated by [9] who disclosed that Muslim and non-Muslim consumers do consider halal products as clean, safe, nutritious and strictly follow the Islamic dietary law.

[10] explored behavior of Muslim consumers with respect to buying halal meat from halal butchers and supermarket. Buying influences were identified and further examined to spot preferences. The study discovered that most Muslims favour local shops when buying halal meat and thus, do not trust big supermarkets. [11] run a more technical study to explore the production and processing of halal meat throughout its supply chain. Islamic dietary prescriptions and the halal meat chain consists of quite a number of key points identified as halal breeding, animal welfare, stunning, knife, slaughter person, slaughter method, invocation, packaging and labelling, and retailing. Uncertainty regarding halal status of a product is lessen as halal principles are met at each of these points.

\section{AtTitude AND BeHAVIORAL INTENTION}

The role of attitude in justifying consumers' behavioral intention can be found in many research studies. Among them were the research works of [3] and [12] who disclosed that attitude hold a significant and positive effect on halal food purchasing intention. The study noticed that greater intention to purchase halal food products is to be drawn from consumers' positive attitude toward halal food. This was further supported by [13] whose study explored about the non-Muslims' awareness of halal principles. The research result suggested that positive attitudes towards halal principles contributed to the intention of purchasing halal food products.

Other interesting study in relation to attitude and behavioral intention can be found in [14] who supported the idea that attitude leads to intention. The researcher noted a positive and significant relationship between attitude and behavioral intention to patronage halal restaurants. Research studies by [10] and [15] discovered that most Muslim consumers favour local shops or halal butchers when buying halal meat as they consider authenticity to be the most essential factor. A similar pattern of attitude was found in [16] who recorded that the intention to take halal meat is significantly related to consumers' positive attitude towards the consumption of halal meat.

\section{SUbJECTIVE NORM AND BEHAVIORAL INTENTION}

There is very strong common belief that those who committed to their religious group are more liable to normative influences. Research investigation by [16], for example, had unveiled a significant relationship between peer pressures and behavioral intention. This was further supported by [17] and [12] whose research finding showed that subjective norm was the most influential predictor to consumers' behavioral intention. Research results in [14] provide additional support to such relationship. The study demonstrated that consumers' intention to patronage foodservice premises was found out to be positively associated with subjective norm. The same conception was further discussed in [3] that social pressure is remained essential in influencing consumers' intention to purchase halal food.

Other relevant examples can also be obtained from different research settings. For an instance, the role of subjective norm can effectively be seen in the use of Islamic credit card research study conducted by [18]. The research results disclosed that subjective norm (e.g. financial recommendation) was found to be significant determinant factor for consumers to pursue with Islamic credit card. A study on the non-Muslims' awareness of halal principles which was carried out by [13] suggested that the pressures of others (e.g. living in the Muslim society) rouse the intention to buy halal food products. In [19], the understanding of non-Muslim toward halal principles was facilitated by factors such as mixing with the Muslims and the existence of halal food advertisement.

\section{Perceived Behavioral Control and BeHAVIORAL INTENTION}

The connection between perceived behavioral control and behavioral intention proposes that consumers who feel to hold certain degree of control over behavior might possibly engage with the behavior. On the contrary, those who feel to hold no control would try to ignore the behavior. Perceived availability of halal foods, for example, may facilitate the purchasing of halal and avoiding the non-halal.

Such relationship had been explored and successfully explained in many research studies. A study carried out by [13] on the non-Muslims' awareness of halal principles suggested that perceived behavioral control (e.g. food safety, environmentally friendly, and fair trade) contribute to the behavioral intention of purchasing halal food products. A similar finding was reported in the research work of [3] that 
perceived behavioral control is an important factor to be hold before purchasing halal food. In this study, a significant relationship came out to exist between perceived behavioral control and the halal food purchasing intention.

Consistent to these research results was the one produced by [16] who found out that consumers' perceived control over consuming the meat is significantly related to their intention to consume halal meat. Likewise, the research results also conformed to [14] that a significant relationship do present between perceived behavioral control and the intention to repatronage foodservice premises.

\section{METHODOLOGY}

\section{A. Samples of the Research Study}

Samples of this research study are drafted solely from the city of Kuching, Malaysia. Data for this study are obtained through a structured questionnaire and the whole questionnaire is divided into two sections. Section A concerns about respondent's background wherein details about gender, religious faction, age, monthly income, education, residential, and occupation are recorded. Subsequently, section B consists of questions about attitude, subjective norm, perceived behavioral control, halal image, and behavioral intention. Participants in this study is meant to age above 20 years old since these groups of ages possess the tendency to liberally choose which retail stores to go for shopping and thus, making an independent purchasing decision. To be in line with the purpose of the study respondents must have come into contact with some retail shopping experience as this may turn out to be a strong basis in evaluating their intention to patronage retail store.

\section{B. Statistical Analysis}

Prior to the distribution of the questionnaires a pilot study was performed and a number of interview sessions were conducted to conform to the needs of adjustment done. The participants in the interview were in the category of religiously knowledgeable individuals. Basic analysis to respondents' answers and comments leads to several adjustments and corrections of the questionnaire. This was especially true in the case of wording used, unclear statement, and misleading questions.

The employment of factor analysis in this study is to summarize patterns of correlations among observed variables and to manifest if variables under study can be explained entirely in terms of a much smaller number of variables. Several runs of factor analysis were carried out and the output of the final run was found to produce six factors with Eigenvalues greater than one, explaining $29.22 \%, 8.51 \%, 6.26 \%, 5.34 \%, 4.51 \%$, and $3.98 \%$ of the variance respectively. The Kaiser-Meyer-Olkin was valued at 0.888 and the Bartlett's test score was significant at 0.000 . Therefore, factor analysis has produced values of KMO (Kaiser-Meyer-Olkin) greater than 0.60 while Bartlett's tests were recorded steadily at $\mathrm{p}<0.05$. The results also demonstrated that the correlation matrix of the variables showed at least some correlations of $r=0.30$ indicating the data suitableness for factor analysis. Kaiser's criterion Eigenvalue readings were greater than 1.0 for the first six factors and this was further supported by an inspection of the screeplot that revealed a clear break after the sixth factor. Factors provided under this factor analysis were named after attitude (ATT), subjective norm (SN), perceived behavioral control (PBC), halal principle knowledge (HPK), halal image (HI) and behavioral intention (BI).

Values of Cronbach's Alpha for each variable are illustrated in Table I of which all variables have the reliability values of 0.6 and more, ranging from 0.635 to 0.849 . Lower Cronbach values which are recorded by "perceived behavioral control" (0.635) and "behavioral intention" (0.666) do not at all affect the internal consistency of the scales as further checks on the inter-item correlation for both scales revealed the values of more than 0.2 . This is clearly in agreement with [20] who recommends that the inter-item correlation values should be within the range of 0.2 and 0.4. Therefore, the Cronbach values for all variables in this research study are acceptable. This implies that the survey's questionnaire is a reliable tool to consistently measure the proposed constructs.

TABLE I: RELIABILITY ANALYSIS

\begin{tabular}{|l|c|c|}
\hline Variable & $\begin{array}{c}\text { No. of } \\
\text { Item }\end{array}$ & Cronbach's Alpha \\
\hline ATT & 4 & 0.849 \\
\hline SN & 6 & 0.819 \\
\hline PBC & 4 & 0.635 \\
\hline HPK & 4 & 0.710 \\
\hline BI & 4 & 0.666 \\
\hline HI & 6 & 0.740 \\
\hline
\end{tabular}

A multiple regression analysis was performed with behavioral intention to patronage retail stores functions as dependent variable while attitude, subjective norm, perceived behavioral control, and halal principle knowledge serve as independent variables. The coefficient of determination $\mathrm{R}^{2}$ of 0.409 (adjusted $\mathrm{R}^{2}$ is 0.404 ) connoted that the independent variables have together explained $41 \%$ of the variance in the dependent variable (see Table II). In other words, there are other additional variables in explaining behavioral intention to patronage retail stores and have not been considered in this study, which offers suggestion for future research directions.

TABLE II: MODEL SUMMARY

\begin{tabular}{|c|c|c|c|c|c|c|c|}
\hline \multicolumn{8}{|c|}{ Model Summary } \\
\hline \multirow[b]{2}{*}{ Model } & \multirow[b]{2}{*}{$\mathrm{R}$} & \multirow[b]{2}{*}{$\begin{array}{c}\mathrm{R} \\
\text { Square }\end{array}$} & \multirow[b]{2}{*}{$\begin{array}{l}\text { Adjusted } \\
\text { R Square }\end{array}$} & \multirow{2}{*}{$\begin{array}{c}\text { Std. } \\
\text { Error of } \\
\text { the } \\
\text { Estimate }\end{array}$} & \multicolumn{3}{|c|}{ Change Statistics } \\
\hline & & & & & $\begin{array}{c}\text { R } \\
\text { Square } \\
\text { Change } \\
\end{array}$ & $\begin{array}{c}\mathrm{F} \\
\text { Change }\end{array}$ & $\begin{array}{c}\text { Sig. F } \\
\text { Change }\end{array}$ \\
\hline 1 & $\begin{array}{r}.64 \\
0^{\mathrm{a}}\end{array}$ & .409 & .404 & .33629 & .409 & 82.225 & .000 \\
\hline $\begin{array}{l}\text { a. Pred } \\
\text { Beh } \\
\text { b. Dep }\end{array}$ & ral & $\begin{array}{l}\text { (Consta } \\
\text { Control } \\
\text { Variabl }\end{array}$ & $\begin{array}{l}\text {, Halal P } \\
\text { attitude, } \mathrm{S} \\
\text { Behaviora }\end{array}$ & $\begin{array}{l}\text { nciple Kno } \\
\text { bjective } \mathrm{N} \\
\text { Intention }\end{array}$ & $\begin{array}{l}\text { wledge, } \\
\text { orm }\end{array}$ & rceived & \\
\hline
\end{tabular}

The $\mathrm{F}$ value in the ANOVA test is 82.225 and is significant at the level of 0.000 , which indicates that the model is suitable for the collected data. In addition, values of variance inflation factors (VIF) for the variables in the study are all less than 10: attitude (1.410), subjective norm (1.609), perceived behavioral control (1.320), and halal principle knowledge (1.270), thus validated that there is no multicollinearity issue among independent variables. This is 
further supported by the tolerance values of more than 0.10 for each independent variable: attitude (0.709), subjective norm (0.621), perceived behavioral control (0.758), and halal principle knowledge (0.787). Therefore, this fitted model is an adequate one for the collected data.

An examination of the t-values (see Table III) shows that attitudes, subjective norms, and perceived behavioral control are significantly related to consumers' behavioral intention to patronage retail stores implying the relationships are fully supported by the data. Scores on the regression hold the subjective norm $(\beta 2=0.397$, $\mathrm{t}$-value 8.877 , and $\mathrm{p}<0.05$ ) to possess the biggest standardized beta coefficient, suggesting that subjective norm is the most important factor claimed by the respondents to influence their intention to patronage retail stores. This is trailed by the attitude $(\beta 1=0.227, \mathrm{t}$-value 5.424 , and $\mathrm{p}<0.05)$ signifying the second most important factor. Perceived behavioral control has shown significant impact on consumers' behavioral intention to patronage retail stores at $\beta 3=0.158, \mathrm{t}$-value 3.909 , and $\mathrm{p}<0.05$, inferring the third most important factor to affect respondents' behavioral intention. Further investigation was carried out on the effect of halal principle knowledge upon the consumers' behavioral intention to patronage retail stores. The regression analysis, however, has established that halal principle knowledge failed to affect consumers' behavioral intention to patronage retail stores $(\beta 4=0.026$, t-value 0.661 , and $\mathrm{p}>0.05)$.

TABLE III: REGRESSION RESULTS ON BEHAVIORAL INTENTION

\begin{tabular}{|l|c|c|c|c|c|c|c|}
\hline \multirow{2}{*}{} & \multicolumn{2}{|c|}{$\begin{array}{c}\text { Unstandardized } \\
\text { Coefficients }\end{array}$} & $\begin{array}{c}\text { Standardized } \\
\text { Coefficients }\end{array}$ & \multirow{2}{*}{ t } & \multicolumn{2}{|c|}{ Sig. } & \multicolumn{2}{c|}{$\begin{array}{c}\text { Collinearity } \\
\text { Statistics }\end{array}$} \\
\cline { 2 - 4 } \cline { 7 - 9 } & B & $\begin{array}{c}\text { Std. } \\
\text { Error }\end{array}$ & Beta & & & Tol & VIF \\
\hline (Const) & 0.581 & 0.488 & - & 1.191 & 0.234 & - & - \\
\hline ATT & 0.381 & 0.070 & $0.227^{*}$ & 5.424 & 0.000 & 0.709 & 1.410 \\
\hline SN & 0.376 & 0.042 & $0.397^{*}$ & 8.877 & 0.000 & 0.621 & 1.609 \\
\hline PBC & 0.105 & 0.027 & $0.158^{*}$ & 3.909 & 0.000 & 0.758 & 1.320 \\
\hline HPK & 0.045 & 0.067 & $0.026^{\text {n.s. }}$ & 0.661 & 0.509 & 0.787 & 1.270 \\
\hline R & 0.640 & & & & & & \\
\hline R Square & 0.409 & & & & & & \\
\hline Adj R Sq & 0.404 & & & & & & \\
\hline F & 82.225 & & & & & & \\
\hline Sig. & 0.000 & & & & & & \\
\hline
\end{tabular}

Dependent Variable: Behavioral intention, ${ }^{*} p<0.05$ and significant, n.s. $=$ non significant

\section{RESEARCH FRAMEWORK AND HYPOTHESES}

Grounding on the previous research studies, this research has proposed a theoretical framework which was adapted from the work research of [21] and [22]. The framework has also introduced halal image as an integration to the Theory of Planned Behavior (see Fig. 1). Application of the Theory of Planned Behavior in this study is to facilitate the author's attempt to answer some doubts about the roles of stores' halal image in promoting retail patronage among Muslim consumers. This is in line with [23] who suggested that religious belief is one of the areas in which the theory can possibly be extended. Therefore, the relationship between attitude, subjective norm, perceived behavioral control, halal image and behavioral intention is proposed in the research framework (see Fig. 1).

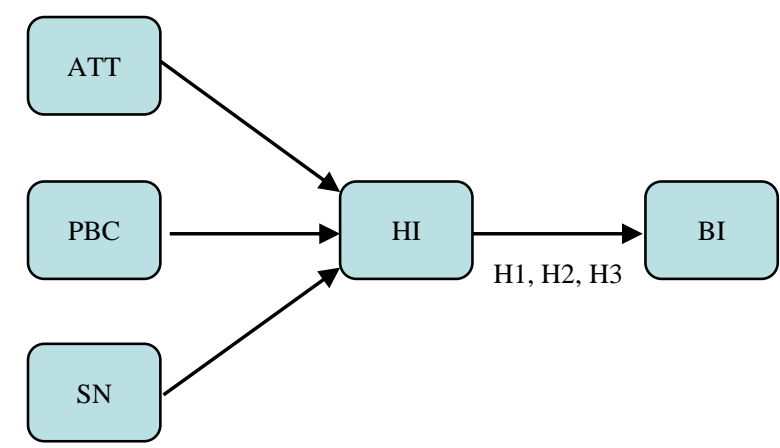

Source: Adapted from [21] and [22]

Fig. 1. Research framework.

Images of halal in retail premises should turn out to be an advantage to retailers who have proactively adapted to halal business concept. A study by [24], for example, disclosed that a favorable image influences repeating consumer patronage. This was further supported by [25] who revealed that a tendency for higher degree of consumer loyalty is to be present as favorable consumer perceptions toward an organization are well preserved. As it is now, Muslims are keen on attaching themselves with halal images and at the same time, tend to avoid or move away from the non-halal images. Thus, integrations of retail halal image within the consumers attitude, subjective norm, perceived behavioral control, and behavioral intention, lead to the following hypotheses:

H1 Halal image significantly mediates the relationship between consumer's attitude and their behavioral intention to patronage retail stores

H2 Halal image significantly mediates the relationship between consumer's subjective norm and their behavioral intention to patronage retail stores

H3 Halal image significantly mediates the relationship between consumer's perceived behavioral control and their behavioral intention to patronage retail stores

\section{SOBEL TeSt}

In this research study, Sobel test [26] is applied in order to know whether halal image could give effect to the relationship between attitude, subjective norm, and perceived behavioral control to behavioral intention. Table IV shows the mediation effect of halal image generated thru Sobel test.

TABLE IV: TEST STATISTIC FOR SOBEL TEST

\begin{tabular}{|l|c|c|}
\hline & Test statistic & $p$-value \\
\hline ATT & 5.753 & 0.000 \\
\hline SN & 5.135 & 0.000 \\
\hline PBC & 5.176 & 0.000 \\
\hline
\end{tabular}

Source: Adapted from [26]

H1 tested that halal image significantly mediates the 
relationship between attitude and behavioral intention to patronage retail stores. The regression analysis of attitude and halal image produces the raw coefficient value of 0.780 with standard error of 0.079 . Raw coefficient for the association between halal image and behavioral intention is recorded at 0.269 with standard error of 0.038 (see Fig. 2). Based on these values the test statistic for Sobel test is calculated and produces the 5.753, with an associated pvalue of 0.000 (see Table IV). The p-value does fall below the established alpha level of 0.05 which specifies that the linkage between the attitude and the behavioral intention is reduced significantly by the insertion of the halal image in the model, inferring that there is evidence of mediation. Thus, $\mathrm{H} 1$ is maintained.

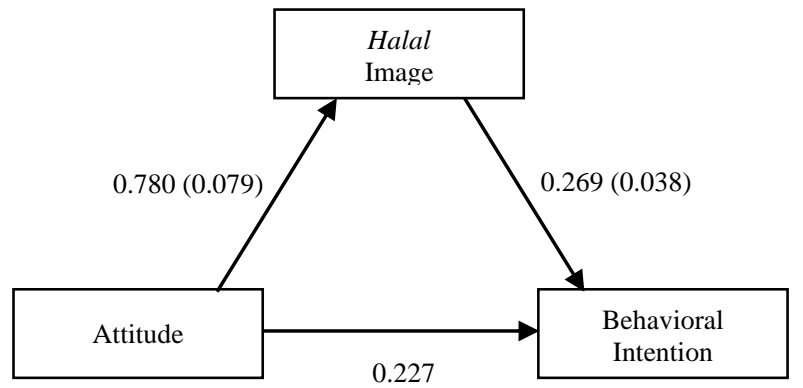

Fig. 2. Halal image significantly mediates the relationship between attitude and behavioral intention to patronage retail stores.

Next, $\mathrm{H} 2$ posits that halal image significantly mediates the relationship between subjective norm and behavioral intention to patronage retail stores. The regression analysis of subjective norm and halal image produces the raw coefficient value of 0.449 with standard error of 0.044 . Raw coefficient for the association between halal image and behavioral intention is recorded at 0.208 with standard error of 0.035 (see Fig. 3). Based on these values the test statistic for Sobel test is calculated and it generates positive result for the subjective norm (see Table IV). Meaning that there is significant mediating effect of halal image on the relationship between subjective norm and behavioral intention (Sobel test $=5.135, \mathrm{p}<0.05)$. Result showes that mediation of halal image exist between subjective norm and behavioral intention (see Fig. 3).

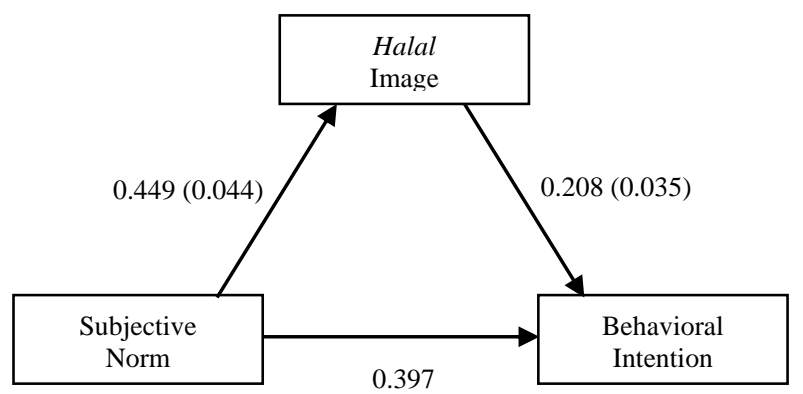

Fig. 3. Halal image significantly mediates the relationship between subjective norm and behavioural intention to patronage retail stores.

Finally, H3 postulates that halal image significantly mediates the relationship between perceived behavioral control and behavioral intention to patronage retail stores. The regression analysis of perceived behavioral control and halal image produces the raw coefficient value of 0.213 with standard error of 0.033. Raw coefficient for the association between halal image and behavioral intention is recorded at 0.312 with standard error of 0.036 (see Fig. 4). Based on these values the test statistic for Sobel test is calculated and further assessment of the mediation effect of halal image on perceived behavioral control and behavioral intention reveals the test score of 5.176 and the p-value is 0.000 , implying moderation role of halal image is significant (see Table IV). Hence, H3 is retained of which halal image mediates the relationship between perceived behavioral control and behavioral intention (see Fig. 4).

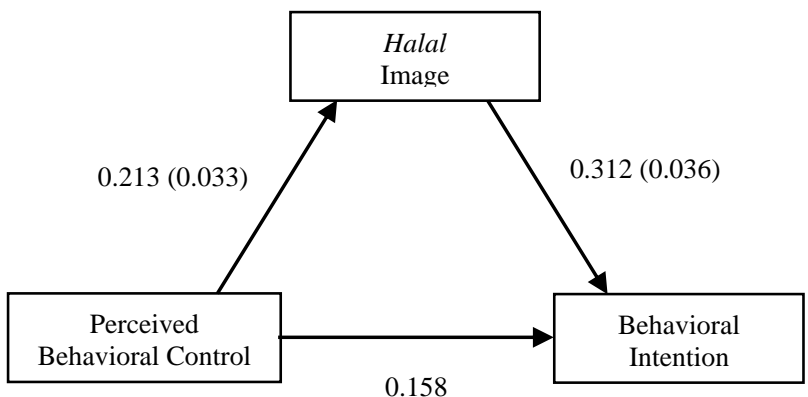

Fig. 4. Halal image significantly mediates the relationship between perceived behavioral control and behavioral intention to patronage retail stores.

\section{DisCUSSION OF FINDINGS}

Result produced by Sobel test in relation to attitude and behavioral intention demonstrates that the mediation of halal image exists between the independent and dependent variable. This suggests that attitude does have an indirect positive relationship with behavioral intention when it is mediated by halal image. With halal image, consumers' attitude toward their intention to patronage retail stores can be further enhanced. Consumers with high attentiveness of the stores' halal image may possibly hold a positive impression toward the stores, a high motivation to patronage, and without any conditions, may follow through their intention to patronage the stores. On the contrary, those who are less aware about the stores' halal image may lack the motivation to patronage and may possibly not follow through their intention to patronage the stores.

Sobel test's result confirms that the relationship between subjective norm and behavioral intention can be influenced by the existence of halal images. This finding reveals that halal image successfully mediates the relationship between subjective norm and behavioral intention. In other words, with the intervention from halal image, social forces are easily prompting the consumers' behavioral intention. Family members or work colleagues, for example, may positively influence consumers to like the stores, but with the presence of stores' halal image, the consumers may be further encouraged to go on with their intention to patronage the stores. In the same way, the consumers may be negatively influenced by the absence of the stores' halal image. This may lead the consumers to engage less with the stores and as a consequence, consumers may not be well motivated to follow through their next intention to patronage the stores. 
Sobel test also reveals that the impact of halal image, which plays a mediator to the relationship between perceived behavioral control and consumers' behavioral intention, is significantly present. With the existence of halal image, the consumers' intention to patronage retail stores can securely be predicted by the consumers' perceived control over the behavior. Consumers with better perceived behavioral control may find it easy to go along with the stores. However, halal image of the stores may highly reassure their intention to patronage the stores. In other setting, poorly perceived behavioral control and lack of halal image generated from the stores may cause the consumers to create a big gap toward the stores, not being motivated to patronage and may not continue with their intention to patronage the stores.

Result of the study suggests that consumers may perceive halal image as an important part in an indirect positive relationship between independent variables (e.g. attitude, subjective norm, and perceived behavioral intention) and behavioral intention, thus giving support to the mediating effect of halal image. A possible explanation for this mediating effect is probably due to the high degree of dependency on halal image. Possessing the knowledge about the true halal image and realizing the essential of pursuing the halal commandment, Muslim consumers may be very cautious while dealing with retail stores. They become quite selective of where or what stores to patronage. To this extent, Muslim consumers have developed their own halal standard and this turns out to be their unique identity. As they go along in deciding which stores they should go for shopping, the least is that it must fit to this halal standard. With this in everybody's mind, halal image must be present to catch the consumers' attention and the key idea of halal image is to inform them that the store is complying with the consumers' halal standard.

\section{CONCLUSION}

Findings of this research study offer the managers and the bodies of authority a better understanding in dealing with Muslim consumers' consumption behavior. In a direct relationship, the study's results indicate that attitude, subjective norm, and perceived behavioral control are strong determinants of consumers' behavioral intention. In an indirect relationship, the study's result reveals that halal image affects attitude, subjective norm, and perceived behavioral control in predicting consumers' behavioral intention.

For the sake of meeting or exceeding consumers' expectation, this study suggests that managers should start to concentrate on educating halal principles to consumers. For instance, retailers may publicly show videos concerning store safety, hygienic practice, food preparation process, halal certification, and the stores' halal policy, to name a few. Images of halal can also be presented in a form of graphic works such as a gigantic poster of chicken with a valid halal logo. Managers must ensure that the practice of halal is gazetted in the company's standard operating procedure so that it will become a business and a work culture. Educating consumers about halal principle means to fine tune their attitudes toward supporting the store.
Consumers with the right halal attitude are expected to spread this idea out to family members, colleagues, and friends. As their perceived control in purchasing halal goods is better, their intention to patronage the store is expected to be higher.

In order for marketing managers to increase store patronage, finding of the study suggests that the managers should keep their concerns in developing a positive Muslim consumers' perception to their stores. A comprehensive study on Muslim consumers' attitude, social outlook, and halal product availability may be a big help in establishing a more relevant marketing policies to anchor a better advertising campaigns, product pricing, merchandising displays, and consumers' safety, to name a few. On the contrary, ignoring consumers' belief in halal principle and paying no attention to consumers' values in halal consumption are not advisable as it might cause a detrimental effect on store patronage. Therefore, promoting these beliefs and values to the communities is noteworthy to the marketing managers as it incites willingness to repurchase, revisit, or recommend the stores to others.

Bodies of authority such as Jabatan Kemajuan Islam Malaysia (JAKIM), local governments, and other supporting agencies should work very closely with retailers to ensure that the stores' halal practice or policies do not mislead consumers and other stakeholders. Realizing the power of halal images in attracting Muslim consumers, aggressively driven retailers may play foul. For example, some retail stores might be hiring Muslim workers to engage with the non-halal foods. In other case, retailers may instruct their non-Muslim workers to wear hijab so that the stores would come out Islamic. As this looks harmful to the Muslim society, the abovementioned bodies should gear up toward this kind of mess by the implementation of halal laws which need to be done in a more friendly, firm, and systematic way.

Therefore, the study proposes that a sincere adaptation of halal principle knowledge and halal image in retail stores is important for the reason that this will add value to retail business, increase Muslim consumers' patronage, and fulfil their corporate social responsibility to the Muslim communities.

\section{CONFLICT OF INTEREST}

The authors declare no conflict of interest.

\section{AUTHOR CONTRIBUTIONS}

Abang Sulaiman Abang Salleh is the main researcher and others are the co-authors who have played their respective assisting roles. Abang Sulaiman Abang Salleh had conducted the research and wrote the paper; Norazah Mohd Suki analyzed the data; Norzaihan Hashim, Abang Sulaiman Abang Naim, and Norlelawati Ismawi were the technical advisors; all authors had approved the final version.

\section{REFERENCES}

[1] Z. A. Alserhan, "Researching muslim consumers: Do they represent the fourth-billion consumer segment?" Journal of Islamic Marketing, vol. 3, no. 2, pp. 121-138, 2012.

[2] K. M. Hashim, The Modern Compendium of halal Volume I: The Essence of Halal, Kuala Lumpur, Malaysia: MDC Publisher. 
[3] S. S. Alam and M. S. Nazura, "Applying the theory of planned behavior (TPB) in halal food purchasing," International Journal of Commerce and Management, vol. 21, no. 1, pp. 8-20, 2011.

[4] Q. Hamouri, "Rationality, time and accounting," Journal of Islamic Marketing, vol. 2, no. 1, pp. 83-96, 1991.

[5] M. Mutsikiwa and C. H. Basera, "The influence of socio-cultural variables on consumers' perception of halal food products: A case of Masvingo Urban, Zimbabwe," International Journal of Business and Management, vol. 7, no. 20, p. 112, 2012.

[6] A. Sanep, W. Hairunnizam, and K. Surtahman, Penjenamaan Halal: Satu Paradigma Baru, Bandar Baru Nilai, Negeri Sembilan: Universiti Sains Islam Malaysia, 20072007.

[7] J. Ireland and S. A. Rajabzadeh, "UAE consumer concerns about halal products," Journal of Islamic Marketing, vol. 2, no. 3, pp. 274 283, 2011.

[8] M. Abdul, H. Ismail, H. Hashim, and J. Johari, "Consumer decision making process in shopping for halal food in Malaysia," China-USA Business Review, vol. 8, no. 9, pp. 40-47, 2009.

[9] H. S. Hasnah, "Consumption of functional food model for Malay muslims in Malaysia," Journal of Islamic Marketing, vol. 2, no. 2, pp. 104-124, 2011.

[10] A. Ahmed, "Marketing of halal meat in the united kingdom: Supermarkets versus local shops," British Food Journal, vol. 110, no. 7, pp. 655-670, 2008.

[11] K. Bonne and W. Verbeke, "Religious values informing halal meat production and the control and delivery of halal credence quality," Agriculture and Human Values, vol. 25, no. 1, pp. 35-47, 2008.

[12] A. Mukhtar and M. M. Butt, "Intention to choose halal products: The role of religiosity," Journal of Islamic Marketing, vol. 3, no. 2, pp. 108-120, 2012.

[13] R. Golnaz, M. Zainalabidin, S. M. Nasir, and C. F. Eddie, "NonMuslims' awareness of halal principles and related food products in Malaysia," International Food Research Journal, vol. 17, pp. 667 674, 2010.

[14] Al-Nahdi, Intention to Patronage halal Restaurants among Malaysian Muslims An Issue of halal Perception, USM, 2008.

[15] K. Bonne and W. Verbeke, "Muslim consumer's motivations towards meat consumption in Belgium: Qualitative exploratory insights from means-end Chain analysis," Anthropology of Food, no. 5, 2006.

[16] K. Bonne, I. Vermeir, F. Bergeaud-Blackler, and W. Verbeke, "Determinants of halal meat consumption in France," British Food Journal, vol. 109, no. 5, pp. 367-386, 2007.

[17] L. Suddin, G. H.Tanakinjal, and A. Hanudin, "Predicting intention to choose halal products using theory of reasoned action," International
Journal of Islamic and Middle Eastern Finance and Management, vol. 2, no. 1, pp. 66-76, 2009.

[18] A. Hanudin, "Patronage factors of Malaysian local customers toward Islamic credit cards," Management Research Review, vol. 35, no. 6 , pp. 512-530, 2012

[19] G. Rezai, Z. Mohamed, and M. N. Shamsudin, "Non-Muslim consumers' understanding of halal principles in Malaysia," Journal of Islamic Marketing, vol. 3, no. 1, pp. 35-46, 2012.

[20] S. R. Briggs and J. M. Cheek, "The role of factor analysis in the development and evaluation of personality scales," Journal of Personality, vol. 54, no. 1, pp. 106-148, 1986.

[21] I. Ajzen, "From intentions to actions: A theory of planned behavior," in J. Kuhl and J. Beckmann, Eds. Action-Control: From Cognition to Behavior, Heidelberg, Germany: Springer, 1985, pp. 11-39.

[22] I. Ajzen, "The theory of planned behavior," Organizational Behavior and Human Decision Processes, vol. 50, no. 2, pp. 179-211, 1991.

[23] M. Conner and C. J. Armitage, "Extending the theory of planned behavior: A review and avenues for further research," Journal of Applied Social Psychology, vol. 28, no. 15, pp. 1429-1464, 1998.

[24] A. S. Dick and K. Basu, "Customer loyalty: Toward an integrated conceptual framework," Journal of the Academy of Marketing Science, vol. 22, no. 2, pp. 99-113, 1994.

[25] L. G. Nguyen, "Corporate image and corporate reputation in customers' retention decisions in services," Journal of Retailing and Consumer Services, vol. 8, no. 4, pp. 227-236, 2001.

[26] M. E. Sobel, "Some new results on indirect effects and their standard errors in covariance structure," Sociological Methodology, vol. 16, pp. 159-186, 1986.

Copyright $($ ) 2020 by the authors. This is an open access article distributed under the Creative Commons Attribution License which permits unrestricted use, distribution, and reproduction in any medium, provided the original work is properly cited (CC BY 4.0).

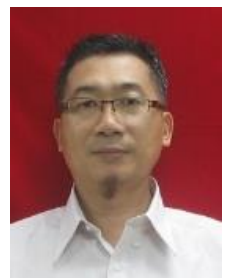

Abang Sulaiman Abang Salleh is an active researcher in the field of halal management and marketing and has contributed articles to international journals. His research interests include Islamic marketing (halal branding, and Islamic hospitality) and Entrepreneurship. He currently serves as a senior lecturer of management /marketing at the Universiti Teknologi Mara Cawangan Sarawak. 